\title{
Employee-Oriented Corporate Social Responsibility (CSR) and Employees Performance, within the Mining Sector
}

\author{
Grace Mulindwa Bahizire* Li FangLin \\ School of Finance and Economics, Jiangsu University, 212013, Zhenjiang, Zhenjiang China
}

\begin{abstract}
Several researches have highlighted the responses of the employees towards the Corporate Social responsibility (CSR) within various business sectors, whereas few studies payed attention to the employees within the mining sector,this paper seeks to investigate the linkage between the employee-oriented CSR and their performance, basically the study focused on a sample of 300 employees of the mining sector in the Democratic Republic of the Congo. The relationship was tested by estimating a linear regression model, the study assessed the mediation mechanism of job satisfaction and organizational commitment.The empirical results showed an evidence of a positive relationship between Employee-oriented Corporate Social Responsibility and job performance, CSR practices towards employees would increase the employee satisfaction, which significantly predicts their job performance, therefore, Employee-oriented Corporate Social Responsibility indirectly impact job performance through mediating mechanism of job satisfaction and organizational commitment.The authors recommended the mining firms to initiate CSR initiatives that involve the workers participation.
\end{abstract}

Keywords: Mining Sector, Corporate Social Responsibility, Human Resources Management,Job perfomance,Job satisfaction, Organizational Commitment.

DOI: $10.7176 / \mathrm{EJBM} / 12-24-07$

Publication date:August $31^{\text {st }} 2020$

\section{Introduction}

The mining sector was preferred as the field of study for this research, firstly, since in the Democratic Republic of Congo, basically the mining sector has the major role as the country's economic engine. Secondly,the mining sector for instance is one among those sectors that have been struggling a lot with the issues related to CSR. Nowadays, Corporate Social Responsibility is seen, more like a business strategy(Porter \& Kramer, 2006), and it has become a topic of great interest in the world of research, in such way that, several researches have emerged in this area (Stephen Brammer, Andrew Millington, \& Bruce Rayton, 2007; Glavas \& Kelley, 2015; Herrera Madueño, Larrán Jorge, Martínez Conesa, \& Martínez-Martínez, 2016; Peterson, 2004; Rodrigo \& Arenas, 2008; RodriguezFernandez, 2016) . wheras (Pan, Sha, Zhang, \& Ke, 2014) studied the corporate social responsibility within the Chinese mining sector, by looking at the different dimension of CSR on the financial performance of the firm. Further (Newman, Nielsen, \& Miao, 2015) looked at the micro apect of it by stuying the impact of CSR on employee performance. Consequently, The rise of CSR is fueled by multiple reasons, companies are receiving more pressure from different groups, the rise of the green market, the socially responsible investors, the growth of ethical investments demonstrates that some investors prefer organizations that do not seek profit maximization by imposing ethical constraints on their operations, more pressure from customers and social media.

However,in this current context of globalization and fierce competition, the growing uncertainties on the global environment are prompting firms to rethink their management methods and their ways of apprehending their employees. In as much as it is necessary for firms to integrate the human resources dimension into the company's strategy. Structures and people give a competitive advantage to the organization. The organizations must have a human and social development strategy in harmony with their economic strategy and social responsibility. Hence, managers' continuous quest for innovative ways to generate greater employees' satisfaction and commitment in today's competitive market is not surprising. By managing a more satisfied and committed workforce, they hope to achieve higher patterns of functioning and widen the competitive advantage of their organizations. Whereby, the mission of human resources management is to develop and mobilize the skills of employees without ignoring the context. There are no universal practices in human resources management (HRM). Successful practices are the ones implanted to in a particular context which enable to overcome challenges, that a firm might face. The human resource magement ought to consider every approach, that will allow in identifying challenges ,the company might face, and adopt the approriate practices, whereof The research for the performance also partly involves the exploration of new forms of organization capable of meeting the challenge in this dynamic world.CSR would be a proper strategy, that human resource management will need to incorporate ,to improve partly the performance of the firms, as researches hold that there is a relationship between Coporate social responsibility and employee performance.

Empirically, the perceptions of employees towards CSR initiatives were studied and found to have great impact on the employee attitudes, thus several researches have concluded that, the CSR practices of the firms have an influence on employees 'attitudes and behavior. Whereby the degree of influence is dependent on the perception 
of employees towards these practices (Bhattacharya \& Sen, 2004). Moreover, the employee's perceptions about the CSR actions would mediate the effect of CSR practices on employees (Rupp, Ganapathi, Aguilera, \& Williams, 2006).

Several researches have been using different structures and measures in studying however until now, no specific or a well-established structure about the CSR perceptions. Several models have been proposed in Marketing and management studies in relation with CSR perceptions.

Generally all the studies, that have attempted to assess the employees perceptions about CSR, so far, were emerging around the concept of caroll's pyramid (Carroll, 1979), based on the well-known four dimensions of social responsibilities (Carroll, 1991 ). Whereby, a good number of studies such as (Maignan, 2001) assumed that the perceptions of consumers and employees about the CSR, ought to be structured according to these four dimensions. In this context, understanding how the perceptions hold by employees of their companies' social performance might contribute to the development of such job attitudes, however, this constitutes a relevant research question.

\section{Literature Review}

\subsection{The Mining sector in the Democratic Republic of Congo}

A nation with the highest world reserve of cobalt, coltan, copper, diamond, tantalum, tin and gold, whereby The mining sector is the largest source of export income of the Country.Although the country is endowed with such high minerals resources, the DRC mining sector has so much controversory, several grave labor violations, child labor in the mining sector, ,more complaints, that workers health is exposed due to the technological processing of the minerals. It's quite challenging for the mining companies to adopt social initiative that will benefit or improve the well being of the employees, as it seems in this sector firms are more interested in fulfilling the primary goal of the business,for instance,mining sector being one the sectors that have been struggling a lot with the issues related to CSR, managers are called to implement strategies, in order to reduce the environmental impact for the wellbeing of the society, and to improve the well-being of workers. However, incorporating the corporate social responsibility , as a business approach, in the mining, it will help human resource managers, it will improve the perfomance of the sector. In Congo the principle of Social Responsibility seems to be an old legal principle which also imposes obligations and responsibilities on firms towards the society. Since the mining sector plays an important role in economic development of the DRC, the mining companies have a huge responsibility towards the Congolese population. As such, the government has promulgated codes, regulations, laws and decrees as instruments for the development and fight against poverty. Thus, the mining sector in the Democratic Republic of Congo mining has been facing serious CSR issues, particularly the labor well-being and community.

\subsection{Employee-Oriented Corporate Social Responsibility}

Basically,when Employee-oriented CSR is successful and sustainable, it leads to value creation for both employees and firms. The value creation for firms is dependent on the increase in commitment and identification with the firm, that the results of successful employee-oriented CSR (Berman et al., 1999). Moreover, successful employeeoriented CSR will improve the company's reputation as an attractive employer in the local community.which will definetly lead to easier recruitment and better retention of skilled and experienced staff. Generally, firms will have a particular image that it communicates internally to its employees, whereby, according to concept of the internal marketing, employees are considered as internal customers that organizations ought to satisfy, in order to get their best. However, employee-oriented CSR in this study emerged from the CSR activities or practices that organizations follow towards their employees,

how employees perceive the CSR actions of their employer may actually have more direct and stronger implications for employees' subsequent reactions than actual firm behaviors of which employees may or may not be aware. (Rupp et al., 2013: 897). But again, the effect would be much bigger, if the CSR activities are designed to first of all support the well-being of the employees.

In most of the business today that have integrated CSR in their strategies, they mainly focused on the customers reactions and perceptions, whereas only few studies have investigated CSR 's influence on the employees 'attitudes and behavior. the existing literatures in the business ethics have made clear, the place of CSR in the work place.as studies show that employees who belong to a socially responsible firm have more commitment towards their jobs, and have good association with the image of the organization. Furthermore, studies have illustrated employees that employees from the socially responsible firms, had high level of motivation, they put considerable efforts in their role, high level of Citizen behavior, better performance, and are more creative at work (Brammer et al. 2015; Glavas and Piderit 2009; Newman et al. 2015). Moreover employees at these firms, tend to have more satisfaction with their job, thus the level of of turn over is reduced among thee wrokers . (Glavas and Kelley 2014; Hansen et al. 2011; Meynhardt et al. 2018). Employees who work in organizations with strong records of CSR show higher levels of commitment, motivation and initiative at work, and tend to be happier with their jobs (Aguinis and Glavas 2017; Brammer et al. 2007; Farooq et al. 2014; Glavas and Kelley 2014), Previous 
research also states that CSR increases employees' motivation to work harder and be more productive (Aguilera et al. 2007; Flammer 2015).

For instance, employees assess the social concern that is embedded in an organization's (procedural CSR), the outcomes that result from such actions (distributive CSR), and how individuals, both within and outside the organization, are treated interpersonally as a result of these actions (interactional CSR). (Rupp et al., 2006: 539) Elikrem's approach CSR as a psychological and perceptual phenomenon and seek to develop a subjective measure that can capture perceived CSR rather than actual CSR actions, Central to employees' reactions are their perceptions of CSR activities (Aguinis \& Glavas, 2012),

As most of the studies while assessing the employees perceptions of CSR, they look at it broadly considering the actions towards all the stakeholders as well the distinctive dimensions of CSR, meanwhile this study attempts to focus only on the CSR activities tailored to maintain and improve the well being of the employees, with respect to the known CSR dimensions, economic, legal, ethical and philanthropic.Although some authors believed that, Employee-oriented CSR and environmental-oriented CSR, it's more like social responsibility and ethical, Shareholder oriented CSR it's more economic, Wheras (Rup et al.(2006) went through with the organizational justice in modelling the CSR perception while taking three dimensions about the employee CSR perceptions, such as the social issues incorporated in the CSR practices known as procedural CSR, the results of those actions which is distributive CSR, and thirdly the interactional CSR is the individual treatment of the people, inside and outside the organization also matters.

\subsection{Job Performance}

Basically, In this context, it is associated with the output in term of quality, quantity,furthermore, the employee pefomance is linked in task performance, the attendance on job, the work efficiency and work effectiveness .However ss the performance is said to be the completion of task on the criteria set by organization or supervisor,whereby in this research the employee performance had to be rated from their surpevisors, and however the employee performance is checked on predescribed acceptable standards while effectively and efficiently using available resources in a changing environment. The Performance can be defined as the result of an execution of a given job or task. According to (Hafiz, 2017) This performance is about the work outcome relatively to effectiveness,efficiency and efficacy. The result of the amount of work accomplished by an employee, however it can be described and evaluated against organizational performance standards. Measures that are commonly used are profitability, productivity, quality, efficiency, and effectiveness. Profitability is said to be ability of an organization to get profit over a longer time period. Effectiveness and efficiency- efficiency is capacity of a person to produce target results with the help of limited resources on the other hand; effectiveness is the capability of a person to meet the target. Wheras, the manager of a company has the responsibility to ensure, tha the business is meeting performance standards or not. However, in order to do so, the suprivesors, set standards for the perfomance, in regard to this, this research reached out to the managers and supervisors, to determine the performance, of the employees. It can be done by establishing standards and goals against performance of an individual. Gernerally Companies confirm that employees are generating products or services of high quality or not, with the help of performance management. The process of management enforces employees to be involved in company planning and thus, participate in role due to motivation of high performance criteria. Performance management consisted of activities which ensure the organizational goals are meeting efficiently and effectively. The performance management system of an organization focuses on employee performance, According to Carlson et al. [37], five practices of human resource management would impact the performances ,however, the morale, competitive compensation, recruitment package, training and development, and performance appraisal are the practices that would influence the employee pefomance.

Previously, studies on employee performance, such as precised that satisfied employees show high level of job performance, job retention, and hapy with their job(Landy, 1985 ), Whereby management can easily motivates the high performer employees to achieve the targets. 
Figure 1: Conceptual framework

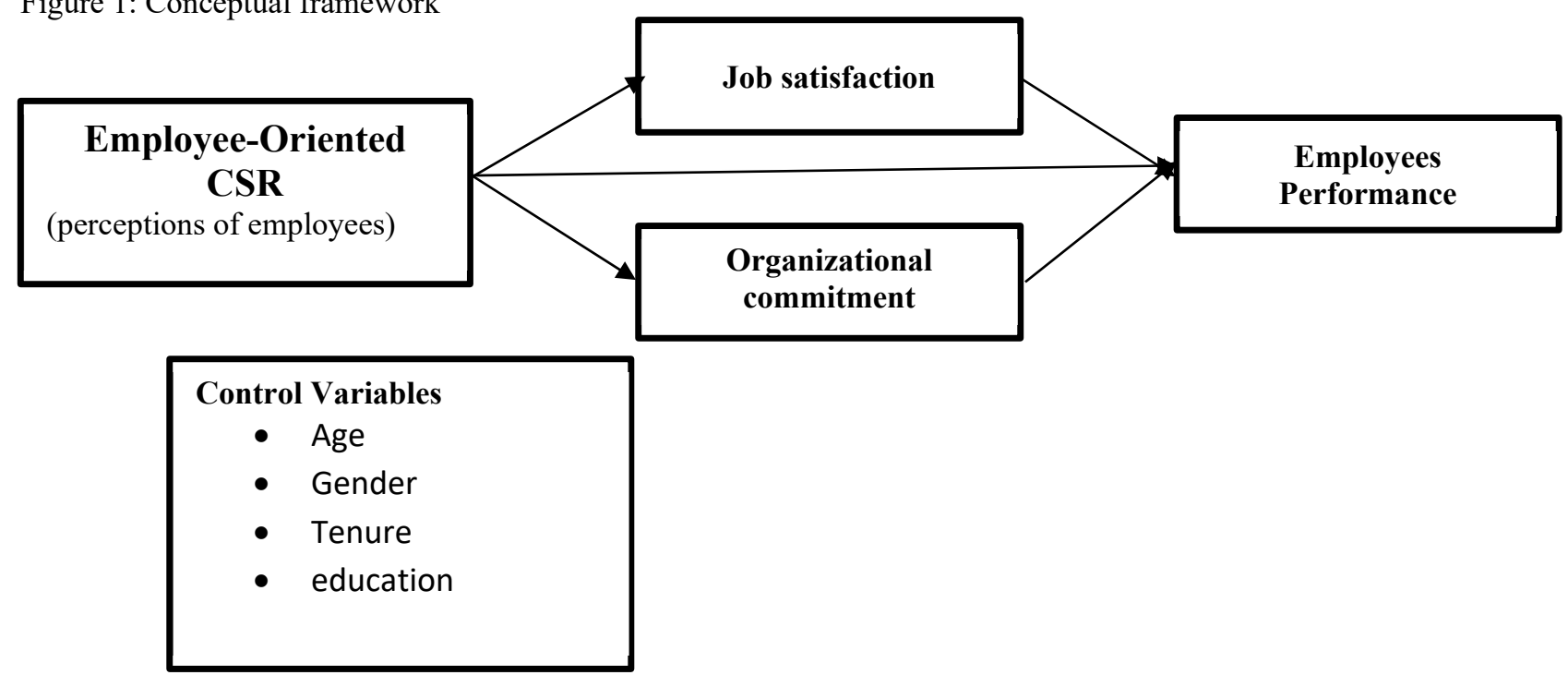

In the figure Fig 1.it illustrates the interconnections among the variable.

\subsection{Development of Hypothesis}

The main purpose of this study was to investigate the effect of the employee oriented-CSR on the job performance, whereas throughtout the literature two import concepts were involved the mechanism of mediating the suggested relationship,whereby Job satisafaction and organizational commiment were proposed to have mediating effects in the suggested relationship.However this research tested three main hypotheses, in overall the study had five hypotheses as shown below in the fig.2.

Figure 2:Hyppotheses diagram

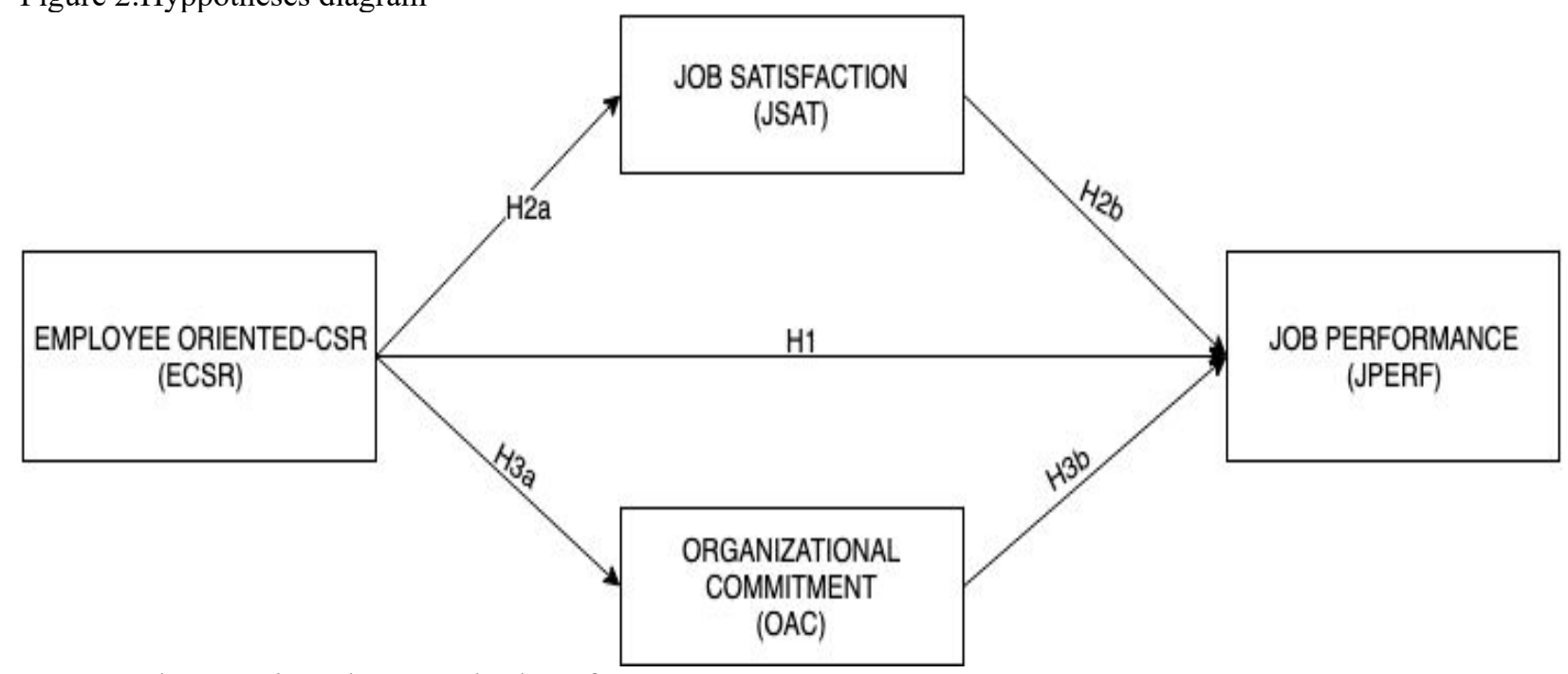

2.4.1 Employee-Oriented CSR and Job performance

According to (Sun, 2015) there is a positive relationship between Corporate social Responsibility and the employee performance, suggesting, that employees are to exhibit better productivity in socially responsible companies and employees are willing to work for less when they work for these companies, in their studies the performance of the employees was measured by the sales and the revenue generated per employee whereby in their study, (Sun, 2015) used an ordinary least squares regression in examining the rapport between corporate social responsibility (CSR) and employee performance. employees are able to be attracted to the socially responsible actions of their organization because CSR activities provide them with a sense of worth and an opportunity to achieve a higher purpose in the workplace, Moreover, an evidence among the Chinese employees, by zhang et al. (2014), after an investigation of the relationship between corporate social performance and Organizational behavior and the results show both were positively related. Therefore, when workers within organizations bear positive perception about their organization, they might go for extra hours, or extra tasks, which might be beyond their daily duties, just because the associate the values with the goals and the interests of the company in which they belong to.

According to several researches, CSR is likely to influence employees 'attitudes and behaviors only if they 
are aware of the actions (Bhattacharya \& Sen, 2004). Whereof, (Fu, 2014 ) concluded that perceived CSR would predict Organizational Citizenship Behavior, withholding the mechanism of the mediating effects of organizational identity and commitment, an evidence of the Chinese hotel industry. (De Roeck, Marique, Stinglhamber, \& Swaen, 2014), in studying the response of employees from the corporate social responsibility, authors considered to have partial mediation role played by overall justice and organizational identification.

Whereas, at the other hand, (Lin, Lyau, Tsai, Chen, \& Chiu, 2010) in their study,conducted among Taiwan workers, found a negative relationship between the philanthropic responsibility and Organizational Citizenship Behavior,

The perception that employees had concerning the investments that organizations would make in CSR activities, is that, employees believed that organizations limitedly involve their resources in activities that are not related to the business operations.

These contradictory findings underscore the need for further investigation to understand the nature of relationships.

This study is attempting to state how Employee-Oriented CSR encourage employees in fully committing themselves in their tasks, role, and behavior towards the betterment of the organizations. As when employees carry positive perceptions of the organization they may go beyond the call of duty to further organization's interest and goals.

H1a: Employee-Oriented CSR relates positively to Job performance.

2.4.2 The mediating role of Job satisfaction

Some Despite the few existing studies analyzing the relationship between perceived CSR and job satisfaction, there are evidences suggesting a positive relationship between the perception's individuals hold of their companies' engagement in socially responsible activities and their levels of satisfaction with the work situation. This relationship seems to occur not only in the case of perceived overall CSR (Tziner et al., 2011), but also in the case of perceptions of corporate engagement in internal socially responsible practices (S Brammer, A Millington, \& B Rayton, 2007) and when individuals assess company's engagement in external practices. Also, this relationship seems to occur not only in what concerns overall job satisfaction but also in the case of employees' satisfaction with specific job aspects.As, then employee-oriented CSR would predict the job satisfaction of employees, meanwhile Job satisfaction is expected to positively affect the performance of the employee at work, therefore the idea that job satisfaction would positively mediate the relationship between the employee-oriented CSR and Job performance is to be hypothesized, as naturally the performance will result from satisfying the need of employees. It has been more than five decades since literature proved the linkage between that job satisfaction and job performance (Brody, 1945).Organizational theories emerged on the notion that organizations, would be able to make their workers happy, they are more likely to have productive workers, throughout the years, the evidence is not completely supporting this notion.distinctive results from the various empirical studies about the relationship between the job satisfaction and job performance, stated higher morale would lead to improved productivity

Hypothesis 2a: Employee-oriented CSR is positively related to job satisfaction.

Hypothesis $2 b$ : Job satisfaction is positively related to job performance.

Hypothesis 2c: Job satisfaction positively mediates the positive relationship between Employee-oriented CSR and job performance

2.4.3 The mediating effect of Organizational commitment

(Turker, 2009) concluded that CSR initiatives oriented toward stakeholders relate positively to employees' organizational affective commitment, that is, their emotional attachment and involvement in the organization. Basically, Three theoretical frameworks seek to explain the positive relationships between CSR initiatives and organizational affective commitment. First, many studies rely on social identity theory and argue that employees commit more to a socially responsible company with which they desire to identify because of its prestigious image (Farooq, Payaud, Merunka, \& Valette-Florence, 2014). Second, employees' perceptions of stakeholder treatment may trigger reciprocating mechanisms (Bosse et al., 2009), such that a generalized social exchange (Molm, Collet, \& Schaeffer, 2007) could explain employees' reactions to Corporate social responsibility, in terms of emotional attachment and intention to engage in exchange relations, that constitute commitment to a caring, generous, and benevolent organization.

According to (Maignan, 2001) socially responsible activities are likely to generate employee commitment, first because they make work activities more enjoyable for employees and second because they translate into visible operations that are likely to generate a feeling of pride among employees".

Organizational commitment is considered as most important concept which influences turnover and job performance(Hafiz, 2017) which also affects the organizational performance.Thus, employee's commitment is essential for organizational performance.Workers become committed when they are are sincere for duty, assigned tasks, and creative towards work(Riketta, 2002). The commitment of employee with an organization is a huge incentive because in this case they will work for organizational goals and also achieve their target (Meyer, Becker, \& Vandenberghe, 2004).

studies support the relation of organizational commitment and employee performance. For example,(Negin, 
Omid, \& Ahmad, 2013 ) explain that organizational commitment influences the job performance of employees within the mining sector.

Hypothesis 3a: Corporate social responsibility is positively related to organization commitment.

Hypothesis $3 b$ : employee commitment is positively related to employee's performance.

Hypothesis 3c: organizational commitment positively mediates the positive relationship between Employeeoriented CSR and employee performance.

\section{Methodology}

The main objective of this research was to study the impact of Corporate Social Responsibility (CSR) on employee, as the study sought further to understand how employees' perceptions of CSR influence their job satisfaction, organizational commitment and Job Performance.however in addressing this question, a quantitive study, whereby data were data through survey questionnaire.

\subsection{Sample}

The data, in this study were collected among the mining sector ,situated in the eastern region of the democatratic republic of the Congo, whereby two forms of questionnaires were distributed, whereby one form was a Self-report measures that allowed to assess the CSR perceptions from the employees,their job satisfaction as well as their organizational commimtment. Meanwhile in overcoming the possibility of common method bias, the job performance were measured from 30 supervisors, who were to rate the perfomances of 300 employees at the work place. The data collection took a month based on demographic profile, age, gender, education, and tenure of temployees,whereby the respondents were between the ages of 21 and $60,16 \%$ were female and $84 \%$ male. Nearly $40 \%$ had second education, and $50 \%$ have diploma ,and around $10 \%$ had first degree.

\subsection{Measures}

\subsubsection{Employee-oriented CSR (ECSR)}

The items to measure this construct,were adopted from (El Akremi, Gond, Swaen, De Roeck, \& Igalens, 2018) ,whereby employee-oriented CSR consist of six items, an example among the itmes "Our company implements policies that improve the well-being of its employees."and they answers were given on a fivepoint scale $(1=$ strongly disagree to $5=$ completely agree). The Cronbach's alpha for this scale was 0.8 Table 1 .

3.2.2 Job satisfaction

Three items were used to measures the Job satisfaction, whereby the items were adopted from (Cho, Ramgolam, Schaefer, \& Sandlin, 2011). The answers were collected in Likert-type scale (1 Strongly disagree and 5 Strongly agree) The Cronbach's alpha for this scale was 0.8 Table 1 .

3.2.3 Organizational commitment

Organizational commitment reflects the affective commitment or the emotional attachement of employees to their organization, and was measured to assess employee-company attachement, five items were consiereded to this scale from (Turker, 2009). Answers were given on a five-point scale ( $1=$ strongly disagree to $5=$ completely agree). The Cronbach's alpha for this scale was 0.7.Table 1.

3.2.4 Job Perfomance

The job performance was measured as In-role performance, whereby it was assessed using 9-item task performance scale developed by Goodman and Svyantek (1999). A typical response item was: 'Competent in all areas of the job, handle tasks with proficiency, The Cronbach's alpha for this scale was 0.9 Table 1.(Cronbach, 1951; Taber, 2018). 
Table 1:Internal consistency and Factor loadings

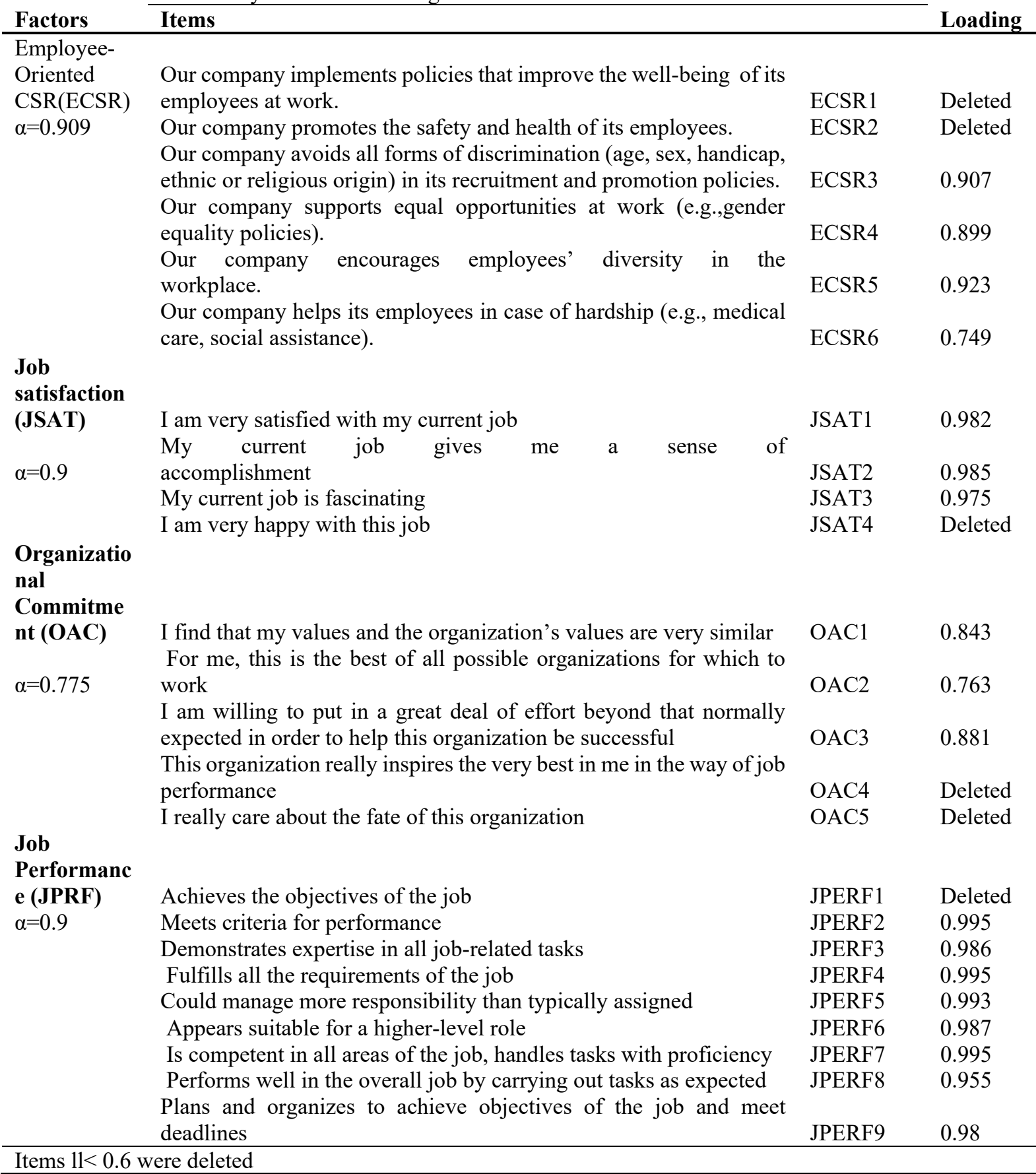

\section{Analysis And Results}

In this study, The data were processed analyzed using the SPSS Statistics 25 software. To validate the construct,an exploratory factor analysis with Principal Components (PCA) was conducted,whereby the results allowed in reducing the number of items and determine the measures to keep for the study appendix.a. Thus, the realibility test was firstly conducted in order to verify the internal consistency of each construct, after that, using a principal component analysis for all the items. The unrotated solution showed no evidence of one dominant common factor, In addition,rotated factor loadings using varimax rotation. Therefore, the results in appendix.a show the constructs load on different factors, confirming validity. Thus, common method bias does not present a significant threat to the study. As the Reliability was tested using estimates of Cronbach's alpha coefficients. However, all the Cronbach's alpha coefficients (ranging from 0.7 to 0.9 ) meet the the recommended value of 0.70 and above, Table 1 .

The table2. illustrates the descriptive statistics and correlations among the variables in this study. However looking at the results, have above average in term of job performance $(\mathrm{M}=3.6, \mathrm{SD}=0.42)$, and tend to evaluate the 
CSR performance of their employing firms as relatively high $(\mathrm{M}=4.37, \mathrm{SD}=0.4)$. Furthermore, above-average means were found for the mediators Job satisfaction $(M=3.28 \mathrm{SD}=0.41)$ and $(\mathrm{M}=3.37, \mathrm{SD}=0.3)$. Secondly, The results of the correlation matrix show that there are significant and positive bivariate relationships between Employee-Oriented CSR and Job performance $(\mathrm{r}=0.78)$, Tenure and job perfomance $(\mathrm{r}=0.65)$, education and job perfomance $(\mathrm{r}=0.63)$, Organizational commitement and Job performance $(\mathrm{r}=0.19)$ Furthermore, CSR shows positive relationships with the mediators job satisfaction $(\mathrm{r}=0.74)$ and organizational commitment $(\mathrm{r}=0.087)$, The mediators are correlated with each other $(\mathrm{r}=0.105)$.

Table 2:Correlation Table and descriptive statistics

\begin{tabular}{|c|c|c|c|c|c|c|c|c|c|c|c|}
\hline S.no & & & & & & & & & & & \\
\hline . & Variables & Mean & SD & 1 & 2 & 3 & 4 & 5 & 6 & 7 & 8 \\
\hline 1 & GENDER & 1.15 & 0.36 & 1 & & & & & & & \\
\hline 2 & AGE & 3.64 & 1.18 & $-.468 * *$ & 1 & & & & & & \\
\hline 3 & TENURE & 3.58 & 0.81 & $-.414 * *$ & $.821 * *$ & 1 & & & & & \\
\hline 4 & EDUCATION & 2.89 & 0.94 & $-.184 * *$ & $.565^{* *}$ & $.482 * *$ & $\begin{array}{l}1 \\
.563 *\end{array}$ & & & & \\
\hline 5 & ECSR & 4.37 & 0.4 & $-.591 * *$ & $.823 * *$ & $.709 * *$ & $\begin{array}{l}* \\
.238 *\end{array}$ & $\begin{array}{l}1 \\
.744 *\end{array}$ & & & \\
\hline 6 & JSAT & 3.28 & 0.41 & $-.518 * *$ & $.581 * *$ & $\begin{array}{l}.530 * * \\
-.185 *\end{array}$ & $*$ & $*$ & 1 & & \\
\hline 7 & $\mathrm{OAC}$ & 3.37 & 0.3 & $-.150 * *$ & $-.147 *$ & $*$ & $\begin{array}{l}.141^{*} \\
.310^{*}\end{array}$ & $\begin{array}{l}0.087 \\
.776^{*}\end{array}$ & $\begin{array}{l}0.105 \\
.648^{*}\end{array}$ & $\begin{array}{l}1 \\
.193 *\end{array}$ & \\
\hline 8 & JPERF & 3.6 & 0.42 & $-.585 * *$ & $.654 * *$ & $.630 * *$ & $*$ & $*$ & $*$ & $*$ & 1 \\
\hline
\end{tabular}

** Correlation is significant at the 0.01 level (2tailed).

* Correlation is significant at the 0.05 level (2tailed).

SD : Standard deviation.

Furher analysis ,in the Table 3. Presents below the results of the mediated regression analysis.whereby a base model was ran to test the effect of Employee oriented- CSR on Job perfomance. However base on th results in this first model (I), The findings show a positive linkage between Employee-Oriented CSR and the Job perfomance. $(b=0.69 ; p<0.01)$, as CSR initiaves that are directly oriented towards the Employees, and would pushed workers to have better performance, therefore the evidence of having a direct relationship between Employee-Oriented CSR and Jo performance,supports the Hyppothesis 1.Moreover, the Sobel test was conducted in investigating the mediation role of Job satisfaction and organizational commitment between the relationship of Employee orientedcsr and job performance, thus the result in the model $2 b$, which provides the evidence supporting the Hppothesis $2 \mathrm{~b}$, as it reveals that the job satisfaction is a mediator of the effect of Employee-Oriented CSR on Job performance $(\mathrm{z}=8,17 ; \mathrm{p}<0.01)$,

the model $3 \mathrm{~b}$ gives the evidence supporting the hypothesis $3 \mathrm{~b}$ and $3 \mathrm{c}$, by revealing the mediation role of Organizational Commitment between Employee-Oriented CSR and Job performance $(\mathrm{z}=3.51 ; \mathrm{p}<0,01)$. The Model 3a supports the Hypothesis 3a, which protays the positive relationship between Employee-Oriented CSR and Organizational Commitment. Employees who perceive their organization to be socially responsible show higher levels of commitment . 
Table 3:mediated regression analysis

\begin{tabular}{|c|c|c|c|c|c|}
\hline Independent Variables & $\begin{array}{c}\text { Job } \\
\text { Performan } \\
\text { ce } \\
{[1]} \\
\end{array}$ & $\begin{array}{l}\text { Job } \\
\text { satisfacti } \\
\text { on } \\
\quad[2 a]\end{array}$ & $\begin{array}{c}\text { Job } \\
\text { performance } \\
{[2 \mathrm{~b}]} \\
\end{array}$ & $\begin{array}{c}\text { Organizational } \\
\text { commitment [3a] }\end{array}$ & $\begin{array}{c}\text { job } \\
\text { performance } \\
{[3 \mathrm{~b}]} \\
\end{array}$ \\
\hline \multicolumn{6}{|l|}{ Employee-Oriented } \\
\hline CSR & $0.69 * *$ & $0.86^{* *}$ & $0.641^{* *}$ & $0.33 * *$ & $0.59 * *$ \\
\hline \multicolumn{6}{|l|}{ Mediators } \\
\hline \multicolumn{6}{|l|}{ Organizational } \\
\hline \multicolumn{6}{|l|}{ Control Variables } \\
\hline Gender & $-0.18^{* *}$ & -0.07 & $-0.17 * *$ & $-0.16^{*}$ & $-0.12 *$ \\
\hline Age & -0.01 & -0.027 & $0.015^{* *}$ & $-0.14 * *$ & 0.027 \\
\hline Tenure & $0.11 * *$ & 0.43 & $0.108^{* *}$ & $-0.103 *$ & $0.143 * *$ \\
\hline Education & $-0.77 * *$ & $-0.11 * *$ & $-0.70 * *$ & $0.9^{* *}$ & $-0.106^{* *}$ \\
\hline Constant & 0.65 & -0.17 & $0.66 * *$ & $2.7 * *$ & -0.19 \\
\hline Adjusted $\mathrm{R}^{2}$ & 0.66 & 0.6 & 0.65 & 0.23 & 0.69 \\
\hline F statistics & 114.41 & 90.643 & 95.683 & 18.906 & 112.747 \\
\hline Indirect Effect & & & $0.5^{* *}$ & & $0.1^{* *}$ \\
\hline Sobel (z)test & & & $8.17 * *$ & & $3.51 * *$ \\
\hline
\end{tabular}

$\mathrm{N}=300$
Significance level
${ }^{*} \mathrm{p}<0.05 ; * * \mathrm{p}<0.01$

\section{Discussion And Conclusion}

The results of this study can be discussed as relatively as important in term of theoretical and managerial contributions.Firstly, From a theoretical point of view, the study was based on the fact that employees perceive CSR initiatives according to their interests as employees,thus by estimating a linear regresssion modelling, has allowed to see, how Employee-Oriented CSR related with their satisafction and their commitment within the work place,more exactly in the mining sector. Employee-oriented CSR is a result of mutual trust between organization and its workers, in order to be sustainable, it starts with firms involving the social values and responsibilities at every HRM aspect in the business, the more CSR initiatives are promoting the well-being of employees,reflects a good Employee-Oriented CSR. Nowadays, Organizations are looking to explore new ways and approaches that will help them increase the organizational performance, whereby ,in this dynamic world of business ,firms ought to implement any initiative that addresses their challenge, and allow the firm to plan for a sustainable future. The performance of a firm can be assured by various forms, such the employees performance.

Employee performance is a key element in predicting the organizational performance,this research recommends to the mining firms ,should to seek new ways of implementing the CSR policies ,bearing in mind the need of employees, the employee-oriented Corporate Social responsibity is likely to increase the employee performance, and as well as keep the workers satisfied and committed to their work. The CSR initiaves that support the wellbeing of the employees, and promotes the employees personal development.Thus, the mining firms in the $\mathrm{DRC}$, would need to transition from the traditional appraisal process to the more enterprising perfomance management process that ties employee perfomance to organizationla perfomance through its mission,vision and values evolving the social responsibility throughout the HRM process.

As, the approach by the corporate social responsibility (CSR),appears to be a new form a HR strategy,whereof, the human resource management,ought to implement in their HRM process, it applies to all sectors, not only in the mining sector, but in all sectors of activity and in developed countries, as in developing ones.

Therefore, CSR is seen as a strategy in managing the human resources and the internal social responsibility of the firm, for the purpose of creating, maintaining and developing the jobs and the human capital of the company in the long term. However,This research suggests that, CSR in the management of human resources should not only be limited to compulsory administrative procedures, but combine the missions linked to recruitment, training, mobility, motivation, loyalty, involvement, skills management and visibility of development prospects. In all the aspects of the human resources management process, supervisors and managers, should ensure that the Corporate Social Responsibility is at the core in dealing with workers , as the internal social responsibility seem to be the major duty of HR managers.Managers, should communicate the Social values and responsibility throughout the HRM process. In the mining sector for in instance, most of the complaints are related to the employees wellbeing,whereby, in the Democratic Republic of Congo, workers are not satisfied with the compensation systm with 
this sector, firms are to verify whether their compensation policies are socially responsible , and this implies to each aspect of the HRM process, HR managers should ensure, that it's socially responsible. This study presents some limits which constitute as many perspectives of future developments, whereby future research will need to considere other mechanisms such as CSR and employees motivations.

\section{Funding Institution}

The research work was fully supported by the National Natural Science Foundation of China and the grant number 71503105 .

\section{Disclosure Statement}

Concerning the realization of this work I declare that there is no conflict of interest that was noted

\section{REFERENCES}

Bhattacharya, C. B., \& Sen, S. (2004). Doing better at doing good: When, why, and how consumers respond to corporate social initiatives. California management review47(1), 9-24.

Brammer, S., Millington, A., \& Rayton, B. (2007). The contribution of corporate social responsibility to organizational commitment. The International Journal of Human Resource Management, 18(10), 1701-1719.

Brammer, S., Millington, A., \& Rayton, B. (2007). The contribution of corporate social responsibility to organizational commitment. The International Journal of Human Resource Management 18 (10), 1701-1719.

Carroll, A. B. (1991 ). The pyramid of corporate social responsibility: Toward the moral management of organizational stakeholders. Business horizons 34(4), 39-48.

Carroll, A. B. ( 1979). A three-dimensional conceptual model of corporate performance.

Academy of Management review, 4(4), 497-505.

Cho, J., Ramgolam, D. I., Schaefer, K. M., \& Sandlin, A. N. (2011). The rate and delay in overload: An investigation of communication overload and channel synchronicity on identification and job satisfaction. Journal of Applied Communication Research, 39(1), 38-54.

Cronbach, L. (1951). Coefficient alpha and the internal structure of tests. Psychometrika, 16(3), 297-334.

De Roeck, K., Marique, G., Stinglhamber, F., \& Swaen, V. (2014). Understanding employees' responses to corporate social responsibility: mediating roles of overall justice and organisational identification. The International Journal of Human Resource Management

25(1), 91-112.

El Akremi, A., Gond, J.-P., Swaen, V., De Roeck, K., \& Igalens, J. (2018). How do employees perceive corporate responsibility? Development and validation of a multidimensional corporate stakeholder responsibility scale. Journal of Management, 44(2), 619-657.

Fu, H., Li, Y. and Duan, Y (2014 ). Does employee-perceived reputation contribute to citizenship behavior? The mediating role International Journal of Contemporary Hospitality Management

26(4), 593-609.

Glavas, A., \& Kelley, K. (2015). The Effects of Perceived Corporate Social Responsibility on Employee Attitudes. Business Ethics Quarterly, 24(2), 165-202. doi:10.5840/beq20143206

Hafiz, A. (2017). Relationship between organizational commitment and employee's performance evidence from banking sector of Lahore. Arabian Journal of Business and Managment Review

7(2), 1-7. doi:10.4172/2223-5833.1000304

Herrera Madueño, J., Larrán Jorge, M., Martínez Conesa, I., \& Martínez-Martínez, D. (2016). Relationship between corporate social responsibility and competitive performance in Spanish SMEs: Empirical evidence from a stakeholders' perspective. BRQ Business Research Quarterly, 19(1), 55-72. doi:https://doi.org/10.1016/j.brq.2015.06.002

Landy, F. (1985 ). The Psychology of Work Behavior Homewood IL: Dorsey Press.

Lin, C., Lyau, N., Tsai, Y., Chen, W., \& Chiu, C. ( 2010). Modeling corporate citizenship and its relationship with organizational citizenship behaviors. Journal of Business Ethics, 95, 357-372. doi: http://dx.doi.org/10.1007/s10551-010-0364-x

Maignan, I. F. (2001). Antecedents and benefits of corporate citizenship: An investigation of French businesses. Journal of Business Research

51(1), 37-51.

Meyer, J. P., Becker, T. E., \& Vandenberghe, J. o. a. p. (2004). Employee commitment and motivation: a conceptual analysis and integrative model. Journal of applied psychology, 89(6), 991. doi: DOI: 10.1037/0021-9010.89.6.991

Negin, M., Omid, M., \& Ahmad, B. (2013 ). The Impact of Organizational Commitment on Employees job performance. A study of Meli Bank. International Journal of Contemporary Research in Business( 5 ), 164171. 
Newman, A., Nielsen, I., \& Miao, Q. (2015). The impact of employee perceptions of organizational corporate social responsibility practices on job performance and organizational citizenship behavior: evidence from the Chinese private sector. The International Journal of Human Resource Management, 26(9), 1226-1242. doi:10.1080/09585192.2014.934892

Pan, X., Sha, J., Zhang, H., \& Ke, W. (2014). Relationship between corporate social responsibility and financial performance in the mineral Industry: Evidence from Chinese mineral firms. Sustainability, 6(7), 4077-4101.

Peterson, D. K. (2004). The Relationship between Perceptions of Corporate Citizenship and Organizational Commitment. Business \& Society, 43(3), 296-319. doi:10.1177/0007650304268065

Porter, M. E., \& Kramer, M. R. (2006). Strategy \& Society: The Link between Competitive Advantage and Corporate Social Responsibility. Harvard Business Review( 84), 78-85.

Riketta, M. (2002). Attitudinal Organizational Commitment and Job Performance: a Meta-Analysis. Journal of Organizational Behavior( 23), 257-266.

Rodrigo, P., \& Arenas, D. (2008). Do employees care about CSR programs? A typology of employees according to their attitudes. Journal of Business ethics, 83(2), 265-283.

Rodriguez-Fernandez, M. (2016). Social responsibility and financial performance: The role of good corporate governance. BRQ Business Research Quarterly, 19(2), 137-151. doi:https://doi.org/10.1016/j.brq.2015.08.001

Rupp, D. E., Ganapathi, J., Aguilera, R. V., \& Williams, C. A. (2006). Employee reactions to corporate social responsibility: An organizational justice framework. . Journal of Organizational Behavior: The International Journal of Industrial, Occupational and Organizational Psychology and Behavior, 27(4), 537-543.

Sun, L. (2015). The impact of corporate social responsibility on employee performance and cost. Review of Accounting and Finance, 14(3), 262-284. doi:10.1108/RAF-03-2014-0025

Taber, K. S. (2018). The Use of Cronbach's Alpha When Developing and Reporting Research Instruments in Science Education. Research in Science Education, 48(6), 1273-1296. doi:10.1007/s11165-016-9602-2

Turker, D. (2009). How corporate social responsibility influences organizational commitment. Journal of Business ethics, 89(2), 189. doi:DOI 10.1007/s10551-008-9993-8 